\title{
Association between calcitonin receptor gene polymorphisms and calcium stone urolithiasis: A meta-analysis
}

\author{
Jiaxuan Qin ${ }^{1}$, Zonglong Cai ${ }^{2}$, Jinchun Xing ${ }^{1}$, Bo Duan ${ }^{1}$, Peide Bai ${ }^{1}$ \\ ${ }^{1}$ Department of Urology Surgery, the First Affiliated Hospital of Xiamen University; Center of Diagnosis \\ and Treatment of Urinary System Diseases, the First Affiliated Hospital of Xiamen University; the Key \\ Laboratory of Urinary Tract Tumors and Calculi of Xiamen City, the First Affiliated Hospital of Xiamen \\ University. Xiamen, Fujian, China; ${ }^{2}$ The First Clinical Medical School of Fujian Medical University. \\ Xiamen, Fujian, China
}

\section{ABSTRACT}

Purpose: It has been reported that calcitonin receptor (CALCR) gene polymorphisms might be associated with calcium stone urolithiasis. Owing to mixed and inconclusive results, we conducted a meta-analysis to summarize and clarify this association.

Materials and Methods: A systematic search of studies on the association between CALCR gene polymorphisms and calcium stone urolithiasis susceptibility was conducted in databases.

Results: Odds ratios and 95\% confidence intervals were used to pool the effect size. Five articles were included in our meta-analysis.

Conclusions: CALCR rs1801197 might be associated with increased risk of calcium stone urolithiasis. There is insufficient data to fully confirm the association between CALCR rs1042138 and calcium stone urolithiasis susceptibility. Well-designed studies with larger sample size and more subgroups are required to validate the risk identified in the current meta-analysis.

\section{ARTICLE INFO}

Jinchun Xing

http://orcid.org/0000-0002-1651-5223

\section{Keywords:}

Receptors, Calcitonin;

Urolithiasis; Meta-Analysis

[Publication Type]

Int Braz J Urol. 2019; 45: 901-9

Submitted for publication: January 29, 2019

Accepted after revision:

May 06, 2019

Published as Ahead of Print:

July 15, 2019

\section{INTRODUCTION}

Urolithiasis is a relatively common health problem which is likely associated with the effects of multiple genes in combination with lifestyles and environmental factors $(1,2)$. Majority of urolithiasis is calcium stone. The calcitonin receptor (CALCR) is a 7-pass transmembrane G-protein-coupled receptor which reacts in response to the calcium metabolism-related hormone calcitonin (3). By binding calcitonin receptor on the osteoclasts in the bone and the renal tubular cells, calcitonin causes inhibition of bone resorption and lowers serum calcium concentration (4). Therefore, calcitonin receptor gene polymorphisms might cause calcium metabolic disorders. Some calcitonin receptor gene polymorphisms, like SNP rs 1801197 $(1377 \mathrm{C}>\mathrm{T})$ and rs 1042138 (3'UTR+18C >T), have 
shown association with bone mineral density (5, 6). The SNP rs1801197 alters the encoded amino acid from proline to leucine (7). Researchers have also investigated the association of those SNPs with urolithiasis.

Association between calcitonin receptor gene polymorphisms and calcium stone urolithiasis susceptibility has been studied in several populations. Sample sizes in these studies are relatively small. Therefore, we decided to perform a meta-analysis to estimate it.

\section{MATERIALS AND METHODS}

\section{Identification of eligible studies}

A systematic search in Pubmed by Medline, Embase, Cochrane Library, clinicaltrials.gov, CNKI (China National Knowledge Infrastructure) databases were carried out by two independent investigators. The following terms were used: "calcitonin Receptor OR CTR OR CALCR" AND "stone OR calculus OR calculi OR lithiasis OR Nephrolithiasis OR urolithiasis" AND "polymorphisms OR polymorphism", without any limitation applied. The last search update was performed on August 3, 2017. References of related studies and reviews were also manually searched for additional studies.

\section{Inclusion and exclusion criteria}

Studies selected in this meta-analysis should have met the following inclusion criteria: (1) evaluation of the association between calcitonin receptor gene polymorphisms and calcium stone urolithiasis susceptibility; (2) case-control study; (3) studies focusing on tissues of human beings; (4) detailed genotype data could be acquired to calculate the odds ratios (ORs) and 95\% confidence intervals (95\% CIs). Exclusion criteria: (1) duplication of previous publications (when there were multiple publications from the same population, only the largest study was included); (2) comment, review and editorial; (3) study without detailed genotype data; (4) GWAS; (5) studies focusing on cell lines. Dissertation thesis were included in the analysis.

Study selection was achieved by two investigators independently, according to the inclusion and exclusion criteria by screening the title, abstract and full-text. Any dispute was solved by discussion.

\section{Data extraction}

Two investigators extracted data of the eligible studies independently. In the case of a conflict, an agreement was reached by discussion. If the dissent still existed, the third investigator would be involved to adjudicate the disagreements. Try to contact the author by email for detailed genotype data.

The following contents were collected: first author's surname, year of publication, chemical composition of urinary calculi, the characteristics of cases and controls, source of control groups, country of origin, the detective sample, ethnicity, genotyping method, Hardy-Weinberg equilibrium, number of cases and controls for each genotype.

\section{Methodological quality assessment}

The qualities of included studies were evaluated independently by two investigators according to Newcastle-Ottawa Scale (NOS) (8) and the most important factor was "age, gender and country". Quality scores range from 0 to 9 , and higher scores meant better quality of the study. Disagreement was resolved through discussion.

\section{Statistics analysis}

Our meta-analysis was conducted according to the PRISMA checklists (9). Hardy-Weinberg equilibrium (HWE) was evaluated for each study by Chi-square test in control groups, and $\mathrm{P}<0.05$ was considered as a significant departure from HWE. OR and 95\% CIs were calculated to evaluate the strength of the association between calcitonin receptor gene polymorphisms and calcium stone urolithiasis susceptibility. Pooled ORs were obtained from combination of single studies by allelic comparison (T vs. C), dominant model (CT+TT vs. CC), recessive model (TT vs. $\mathrm{CC}+\mathrm{CT}$ ), homozygote comparison (TT vs. $\mathrm{CC}$ ) and heterozygote comparison (CT vs. CC), respectively. The statistical significant level was determined by Z-test with $P$ value less than 0.05 .

Heterogeneity was evaluated by Q-test and $\mathrm{I}^{2}$ index (10). When Q-test's P-value was less than 0.10 and/or $\mathrm{I}^{2}$ index was more than 50\%, the random- 
-effects model (DerSimonian and Laird method) was used; otherwise, the fixed-effects model (Mantel and Haenszel method) was conducted (11).

Sensitivity analyses were performed towards each genetic model to evaluate effect of each study on combined ORs by sequentially excluding each study in total and in any subgroup including more than two studies. Potential publication bias was checked by Begg's funnel (12) plots and Egger's test (13). An asymmetric plot, the $\mathrm{P}$ value of Begg's test $\left(\mathrm{P}_{\mathrm{B}}\right)$ less than 0.05 , and the $P$ value of Egger's test $\left(\mathrm{P}_{\mathrm{E}}\right)$ less than 0.05 was considered a significant publication bias. All statistical analyses were performed with Stata 12.0 software (StataCorp, College Station, Texas, USA). A two-tailed $\mathrm{P}<0.05$ was considered significant except for specified conditions, where a certain $\mathrm{P}$ value was declared.

\section{RESULTS}

Characteristics of studies

A total of 70 articles were acquired from databases (Pubmed by Medline $=6$, Embase $=9$, Cochrane $=0$, clinicaltrials.gov $=0, \quad \mathrm{CNKI}=55$, other sources (from manually search) $=0$ ). The selection process is shown in Figure-1. Three full-text articles were excluded (1 duplicate study (14), 1 GWAS (15), 1 not about urolithiasis (16)). Finally, 5 articles (17-21) were included in our meta-analysis. The characteristics of each study are shown in Table-1 and Table-2. Different genotyping methods were utilized including PCR-RFLP, PCR-SSCP and Sequencing. Blood samples were used for genotyping in all studies. The control group of study NO 1.4, 1.5 and 1.5.1 had shown significant departure from HWE.

\section{Overall analyses and Subgroup analyses}

Summary results of each genetic model are listed in Table-3. In pediatric urolithiasis subgroup and overall, significantly increased risk of calcium stone urolithiasis was found in CALCR rs1801197 in all genetic models. In adult urolithiasis and its male subgroup, significantly increased risk of calcium stone urolithiasis was found in CALCR rs1801197 in heterozygote comparison (CT vs. CC) and dominant model (CT+TT vs. CC). In adult urolithiasis, significantly increased risk

Figure 1 - Flow Chart of study selection.

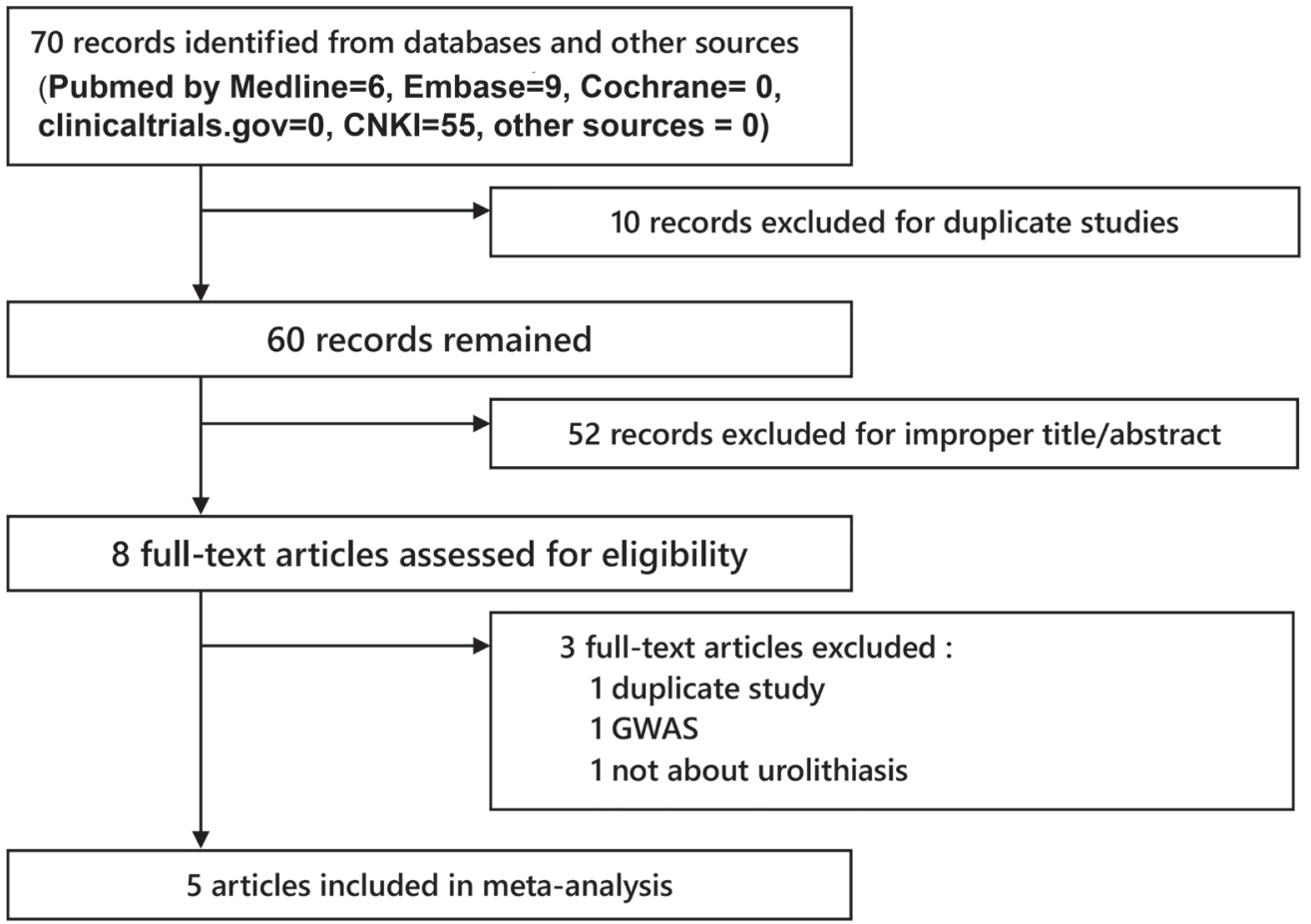


Table 1 - Characteristics of studies included in the meta-analysis.

\begin{tabular}{|c|c|c|c|c|c|c|c|c|c|c|c|c|c|c|}
\hline \multirow[t]{2}{*}{ NO. } & \multirow{2}{*}{$\begin{array}{l}\text { Study ID } \\
\text { CALCR } \\
\text { rs } 1801197\end{array}$} & \multirow[t]{2}{*}{ Year } & \multirow{2}{*}{$\begin{array}{l}\text { Country } \\
\text { or Area }\end{array}$} & \multirow{2}{*}{ Ethnicity } & \multirow{2}{*}{$\begin{array}{l}\text { Control } \\
\text { Type }\end{array}$} & \multirow{2}{*}{$\begin{array}{l}\text { Genotyping } \\
\text { Method }\end{array}$} & \multicolumn{3}{|c|}{ Case } & \multicolumn{3}{|c|}{ Control } & \multirow{2}{*}{$\begin{array}{l}\text { P for } \\
\text { HWE* }^{*}\end{array}$} & \multirow[t]{2}{*}{ Quality } \\
\hline & & & & & & & TT & CT & CC & TT & CT & CC & & \\
\hline 1.1 & Bid HK (17) & 2005 & $\begin{array}{l}\text { Northern } \\
\text { India }\end{array}$ & Indian & $\mathrm{PB}^{*}$ & PCR-RFLP & 10 & 24 & 16 & 4 & 26 & 30 & 0.604 & 9 \\
\hline 1.2 & Song GL (18) & 2014 & China & Uyghur & PB & PCR-RFLP & 4 & 23 & 62 & 0 & 21 & 100 & 0.296 & 9 \\
\hline 1.3 & $\begin{array}{c}\text { Chen WC } \\
\text { (19) }\end{array}$ & 2001 & Taiwan & Asian & PB & PCR-RFLP & 2 & 25 & 75 & 0 & 6 & 99 & 0.763 & 7 \\
\hline 1.3.1 & Male & & & & & & 2 & 18 & 56 & 0 & 0 & 60 & $N A^{*}$ & \\
\hline 1.3.2 & Female & & & & & & 0 & 7 & 19 & 0 & 6 & 39 & 0.632 & \\
\hline 1.4 & $\begin{array}{c}\text { Shakhssalim } \\
\text { N (20) }\end{array}$ & 2014 & Iran & Caucasian & PB & PCR-SSCP & 17 & 47 & 37 & 17 & 38 & 51 & $0.039^{*}$ & 8 \\
\hline 1.5 & Mitra P (21) & 2017 & $\begin{array}{l}\text { West } \\
\text { India }\end{array}$ & Indian & PB & Sequencing & 24 & 78 & 50 & 6 & 69 & 69 & 0.026 & 9 \\
\hline 1.5.1 & Male & & & & & & 16 & 59 & 37 & 2 & 47 & 56 & 0.026 & \\
\hline \multirow[t]{2}{*}{1.5 .2} & Female & & & & & & 8 & 19 & 13 & 3 & 22 & 14 & 0.159 & \\
\hline & $\begin{array}{c}\text { CALCR } \\
\text { rs1042138 }\end{array}$ & & & & & & TT & CT & CC & TT & CT & CC & & \\
\hline 2.1 & $\begin{array}{l}\text { Shakhssalim } \\
\text { N (20) }\end{array}$ & 2014 & Iran & Caucasian & PB & PCR-SSCP & 1 & 27 & 73 & 0 & 0 & 101 & NA & 8 \\
\hline 2.2 & Mitra P (21) & 2017 & $\begin{array}{l}\text { West } \\
\text { India }\end{array}$ & Indian & PB & Sequencing & 6 & 51 & 95 & 2 & 49 & 93 & 0.110 & 9 \\
\hline 2.2.1 & Male & & & & & & 6 & 40 & 66 & 2 & 34 & 69 & 0.344 & \\
\hline 2.2.2 & Female & & & & & & 0 & 11 & 29 & 0 & 15 & 24 & 0.137 & \\
\hline
\end{tabular}

* HWE: Hardy-Weinberg equilibrium; PB: population-based; NA: not available.

${ }^{*}$ Results with statistical significant difference were marked as bold. 
Table 2 - Characteristics of cases and controls.

\begin{tabular}{|c|c|c|}
\hline Study ID & Case & Control \\
\hline Bid HK (17) & $\begin{array}{l}50 \text { pediatric patients (age range } 2-14 \text { years) with } \\
\text { renal stones from the Northern Indian states of Uttar } \\
\text { Pradesh and Bihar. Patients who had history of bowel } \\
\text { disease, renal tubular acidosis and urinary tract } \\
\text { anomalies were excluded. } \\
\text { Stone composition was verified using Xray } \\
\text { crystallography. } 38 \text { patients had sufficient specimens } \\
\text { available for stone composition analysis: } 64 \% \text { were } \\
\text { whewellite, } 28 \% \text { whewellite and weddellite, and } \mathbf{8} \% \\
\text { whewellite and uricite. }\end{array}$ & $\begin{array}{l}60 \text { healthy children (age range } 4-16 \text { years) who had no } \\
\text { history of stone disease were drawn from the general } \\
\text { population taking care to match age, socioeconomic } \\
\text { status, dietary habits, religion and gender. }\end{array}$ \\
\hline Song GL (18) & $\begin{array}{l}89 \text { pediatric patients (age range } 0.5-7 \text { years) with } \\
\text { upper urinary tract calculi from southern Xinjiang of } \\
\text { China. Patients who had rickets, thyroid dysfunction, } \\
\text { parathyroid dysfunction, symptomatic urinary } \\
\text { tract infection, ureteropelvic junction obstruction, } \\
\text { renal insufficiency, renal tubular acidosis, tumor, } \\
\text { osteoporosis, taking vitamin D or calcium supplements } \\
\text { were. } \\
\text { All stone composition was calcium stone, such } \\
\text { as calcium oxalate, calcium phosphate, calcium } \\
\text { carbonate, etc. }\end{array}$ & $\begin{array}{c}121 \text { healthy children (same age range) who had no } \\
\text { history of stone disease were drawn from the general } \\
\text { population of southern Xinjiang taking care to match } \\
\text { age, gender, socioeconomic status, dietary habits and } \\
\text { religion. }\end{array}$ \\
\hline Chen WC (19) & $\begin{array}{l}102 \text { adult patients (age range } 23-76 \text { years) with } \\
\text { recurrent calcium oxalate stones who had been } \\
\text { treated in the department of urology were included. } \\
\text { Patients who showed symptoms of urinary tract } \\
\text { infections during the } \\
\text { period of stone treatment were excluded. } \\
\text { Stone composition was verified by infrared } \\
\text { spectroscopy revealing calcium oxalate monohydrate, } \\
\text { dihydrate, or a combination of the two. }\end{array}$ & $\begin{array}{c}105 \text { healthy volunteers (age range } 40-87 \text { years) } \\
\text { with no familial history of stone disease, or renal } \\
\text { calcification (following renal ultrasonography tests, as } \\
\text { well as routine tests made from urinary microscopic } \\
\text { hematuria). }\end{array}$ \\
\hline $\begin{array}{l}\text { Shakhssalim } \\
\text { N (20) }\end{array}$ & $\begin{array}{l}105 \text { adult men (age range } 30-55 \text { years) with a } \\
\text { history of recurrent calcium urinary stones who } \\
\text { had at least two recurrent episodes during the past } \\
5 \text { years. Patients with histories of known metabolic, } \\
\text { gastrointestinal, hepatic, renal or endocrinological } \\
\text { diseases, with any anatomic abnormality or obstruction } \\
\text { in the urinary tract, or taking any drugs which may } \\
\text { affect urine composition were excluded. }\end{array}$ & $\begin{array}{l}101 \text { adult men (age range } 30-55 \text { years) were selected } \\
\text { from volunteers who had been referred to the } \\
\text { Ophthalmology Clinic of the Labbafinejad hospital, or } \\
\text { unrelated healthy friends of the patients who did not } \\
\text { express any personal or family history of urolithiasis. } \\
\text { Ultrasonographic examination was performed and men } \\
\text { with any evidence of urolithiasis were excluded. Other } \\
\text { exclusion criteria were similar to those for the case } \\
\text { group. }\end{array}$ \\
\hline Mitra P (21) & $\begin{array}{l}152 \text { adult patients (age range 18-75 years) with } \\
\text { calcium containing renal stone(s) in Kolkata, West } \\
\text { Bengal, India. Patients with histories of known } \\
\text { metabolic, gastrointestinal, renal, endocrinological } \\
\text { disorders or patients taking any drugs like steroids, } \\
\text { diuretics were excluded. } \\
\text { The composition of stone was analyzed by chemical } \\
\text { tests. Only patients with calcium containing kidney } \\
\text { stones were included. }\end{array}$ & $\begin{array}{l}144 \text { age and sex matched healthy individuals from the } \\
\text { same geographical region and socioeconomic status } \\
\text { who was negative in family history for kidney stone. } \\
\text { Ultrasonographic examination was performed to } \\
\text { confirm no evidence of renal stone. }\end{array}$ \\
\hline
\end{tabular}


of calcium stone urolithiasis was also found in CALCR rs1801197 in allelic comparison (T vs. C). No statistically significant changes of calcium stone urolithiasis risk was found in other analyses.

\section{Sensitivity analyses}

Sensitivity analyses were performed in any comparison and any subgroup including more than two studies. In adult urolithiasis and its male subgroup, when study NO 1.4 or 1.5 was excluded, statistically different results were obtained in all genetic models of CALCR rs 1801197. Overall, when study NO 1.1 or 1.5 was excluded, statistically different results were obtained in recessive model (TT vs. $\mathrm{CC}+\mathrm{CT}$ ) of CALCR rs1801197 (Table-3).

Less than three studies were included in PU, Female of AU, ARU, Male of ARU subgroup of rs1801197, and AU, Male of AU subgroup of rs 1042138, so that sensitivity analyses could not be performed.

Other results showed stability in sensitivity analyses (Table-3).
Publication bias

Begg's funnel plot and Egger's test were used to assess the publication bias. Symmetry of funnel plot, $\mathrm{P}$ value of Begg's test $\left(\mathrm{P}_{\mathrm{B}}\right)$ and $\mathrm{P}$ value of Egger's test $\left(\mathrm{P}_{\mathrm{E}}\right)$ were evaluated overall (including studies NO 1.1, 1.2, 1.3, 1.4 and 1.5). No significant publication bias was found in Egger's test in all genetic models of CALCR rs1801197. However, in allelic comparison (T vs. C), heterozygote comparison (CT vs. CC) and dominant model (CT+TT vs. CC) of CALCR rs1801197, study NO 1.3 extended beyond the diagonal line which represents pseudo-95\% CI limits about the effect estimate in funnel plot, meanwhile, the $u$ value $=1.96$ $(\mathrm{u}=\mathrm{z}$ in Begg's test) in those three genetic models. In Begg's test, 1.96 is a critical value.

\section{DISCUSSION}

Overall, we found CALCR rs1801197 was associated with increased risk of calcium stone urolithiasis in homozygote comparison (TT vs. $\mathrm{CC}$ ), and the results showed stability in sensitivity analyses and no publication bias (Figure-2).

Figure 2 - Forest plot with a fixed effect model for the association between CALCR rs1801197 and calcium stone urolithiasis in homozygote comparison (TT vs. CC). For each study, the estimate of $\mathrm{OR}$ and its $95 \% \mathrm{Cl}$ is plotted with a box and a horizontal line. Rhombus: pooled OR and its $95 \% \mathrm{Cl}$.

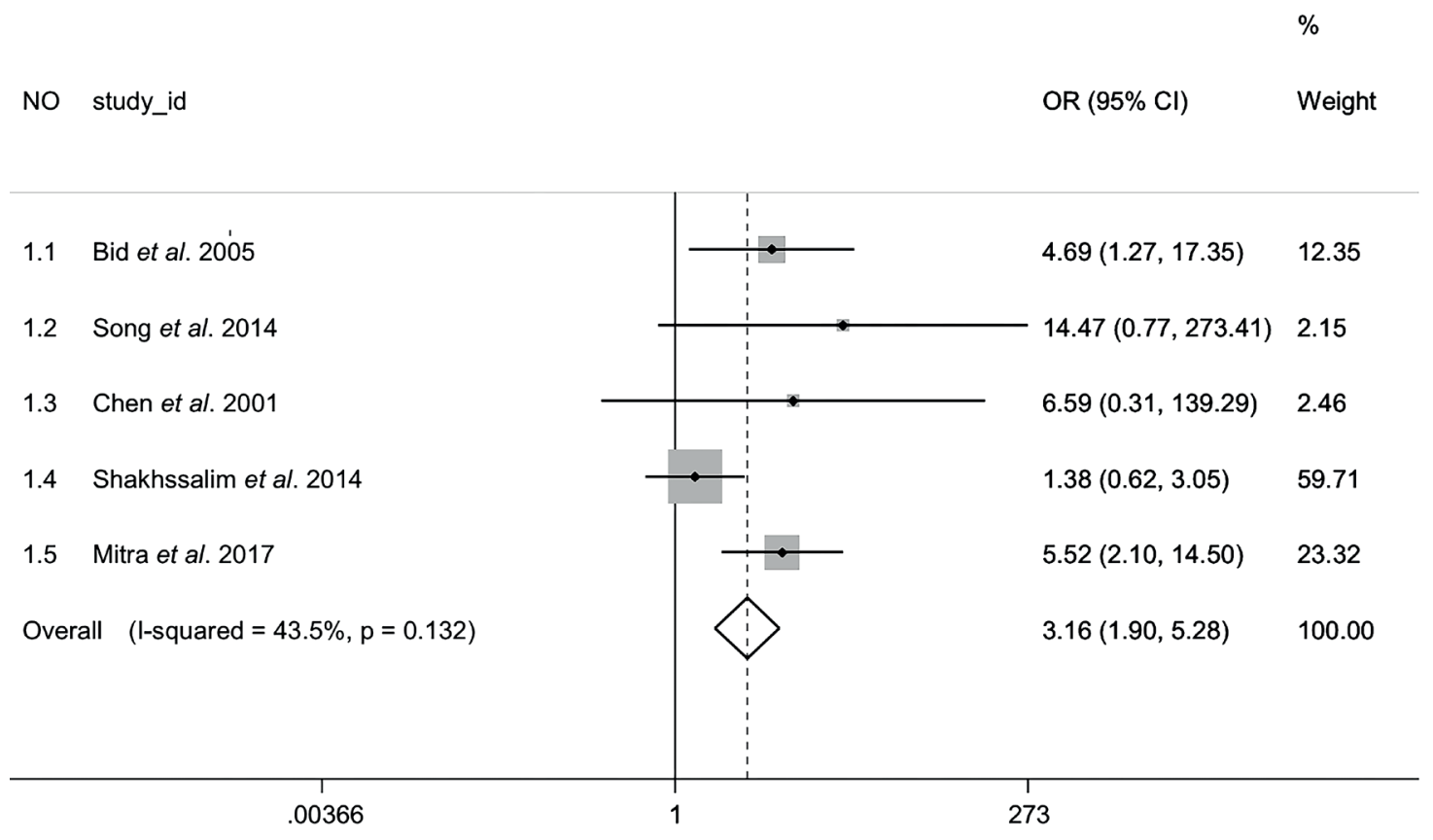


Table 3 - Summary of pooled ORs in the meta-analysis.

\begin{tabular}{|c|c|c|c|c|c|c|c|c|c|c|c|}
\hline & Number & T vs C & & TT vs C & & CT vs CC & & $\mathrm{CT}+\mathrm{TT}$ vs & & TT vs CC+ & \\
\hline CALCR rs1801197 & $\begin{array}{c}\text { (cases/ } \\
\text { controls) }\end{array}$ & $\mathrm{OR}^{\star}\left(95 \% \mathrm{Cl}^{\star}\right)$ & $\mathrm{I} 2(\%)$ & $\mathrm{OR}(95 \% \mathrm{Cl})$ & $\mid 2(\%)$ & $\mathrm{OR}(95 \% \mathrm{Cl})$ & $\mid 2(\%)$ & $\mathrm{OR}(95 \% \mathrm{Cl})$ & $\mid 2(\%)$ & $\mathrm{OR}(95 \% \mathrm{Cl})$ & $12(\%)$ \\
\hline $\begin{array}{l}\text { Overall } \\
\left(1.1^{\star}, 1.2,1.3,1.4,1.5\right)\end{array}$ & $494 / 536$ & $\begin{array}{l}1.987(1.401- \\
2.819)^{*}\end{array}$ & 56.9 & $\begin{array}{c}3.163(1.895- \\
5.279)\end{array}$ & 43.5 & $\begin{array}{c}1.910(1.433- \\
2.544)\end{array}$ & 30.7 & $\begin{array}{l}2.117(1.608- \\
2.787)\end{array}$ & 32.2 & $\begin{array}{l}2.805(1.195- \\
6.587)^{\star}\end{array}$ & 51.0 \\
\hline $\begin{array}{l}\text { PU* } \\
(1.1,1.2)\end{array}$ & $139 / 181$ & $\begin{array}{c}2.094(1.394- \\
3.145)\end{array}$ & 0.0 & $\begin{array}{c}6.140(1.895- \\
19.89)\end{array}$ & 0.0 & $\begin{array}{c}1.752(1.042- \\
2.947)\end{array}$ & 0.0 & $\begin{array}{c}2.095(1.270- \\
3.456)\end{array}$ & 0.0 & $\begin{array}{c}4.631(1.527- \\
14.04)\end{array}$ & 0.0 \\
\hline $\begin{array}{l}\mathbf{A U}^{*} \\
(1.3,1.4,1.5)\end{array}$ & $355 / 355$ & $\begin{array}{c}2.052(1.141- \\
3.690)\end{array}$ & 76.9 & $\begin{array}{c}2.955(0.937- \\
9.315)\end{array}$ & 61.3 & $\begin{array}{c}2.188(1.161- \\
4.126)\end{array}$ & 64.9 & $\begin{array}{c}2.329(1.255- \\
4.323)\end{array}$ & 66.1 & $\begin{array}{c}2.305(0.708- \\
7.500)\end{array}$ & 66.2 \\
\hline $\begin{array}{l}\text { Male of AU } \\
(1.3 .1,1.4,1.5 .1)\end{array}$ & $289 / 271$ & $\begin{array}{c}2.036(0.963- \\
4.305)\end{array}$ & 76.3 & $\begin{array}{c}3.862(0.724- \\
20.61)\end{array}$ & 70.0 & $\begin{array}{c}2.234(1.011- \\
4.935)\end{array}$ & 61.2 & $\begin{array}{l}2.437(1.063- \\
5.586)\end{array}$ & 67.1 & $\begin{array}{c}2.855(0.557- \\
14.64)\end{array}$ & 70.1 \\
\hline $\begin{array}{l}\text { Female of AU } \\
(1.3 .2,1.5 .2)\end{array}$ & $66 / 84$ & $\begin{array}{c}1.541(0.881- \\
2.694)\end{array}$ & 0.0 & $N A^{*}$ & NA & $\begin{array}{c}1.335(0.627- \\
2.840)\end{array}$ & 29.1 & $\begin{array}{c}1.509(0.722- \\
3.154)\end{array}$ & 0.0 & NA & NA \\
\hline $\begin{array}{l}\text { ARU* } \\
(1.3,1.4)\end{array}$ & $203 / 211$ & $\begin{array}{c}2.557(0.605- \\
10.81)\end{array}$ & 88.4 & $\begin{array}{c}1.584(0.746- \\
3.366)\end{array}$ & 0.0 & $\begin{array}{c}2.891(0.918- \\
9.101)\end{array}$ & 76.5 & $\begin{array}{c}2.920(0.808- \\
10.55)\end{array}$ & 82.2 & $\begin{array}{l}1.201(0.595- \\
2.421)\end{array}$ & 1.0 \\
\hline $\begin{array}{l}\text { Male of ARU } \\
(1.3 .1,1.4)\end{array}$ & $177 / 166$ & $\begin{array}{c}5.796(0.141- \\
239.1)\end{array}$ & 85.7 & $\begin{array}{l}1.552(0.728- \\
3.307)\end{array}$ & 0.0 & $\begin{array}{c}\text { 6.349(0.218- } \\
184.6)\end{array}$ & 82.0 & $\begin{array}{l}6.576(0.184- \\
234.4)\end{array}$ & 84.1 & $\begin{array}{c}1.173(0.580- \\
2.371)\end{array}$ & 0.0 \\
\hline \multicolumn{12}{|l|}{ CALCR rs1042138 } \\
\hline $\begin{array}{l}\text { AU } \\
(2.1,2.2)\end{array}$ & $253 / 245$ & $\begin{array}{c}7.502(0.067- \\
843.2)\end{array}$ & 91.1 & $\begin{array}{c}3.150(0.738- \\
13.43)\end{array}$ & 0.0 & $\begin{array}{c}7.477(0.049- \\
1144)\end{array}$ & 92.0 & $\begin{array}{c}7.871(0.054- \\
1144)\end{array}$ & 91.8 & $\begin{array}{c}2.940(0.694- \\
12.46)\end{array}$ & 0.0 \\
\hline $\begin{array}{l}\text { Male of AU } \\
(2.1,2.2 .1)\end{array}$ & $213 / 206$ & $\begin{array}{c}8.130(0.084- \\
787.7)\end{array}$ & 90.4 & $\begin{array}{c}3.321(0.773- \\
14.26)\end{array}$ & 0.0 & $\begin{array}{c}8.191(0.064- \\
1041)\end{array}$ & 91.3 & $\begin{array}{c}8.663(0.073- \\
1029)\end{array}$ & 91.1 & $\begin{array}{c}2.938(0.690- \\
12.51)\end{array}$ & 0.0 \\
\hline
\end{tabular}

*OR: Odds ratio; Cl: confidence interval; PU: Pediatric Urolithiasis; AU: Adult Urolithiasis; ARU: adult recurrent urolithiasis; NA: not available.

*NO of studies included in the meta-analysis.

${ }^{*}$ Results with statistical significant difference were marked as bold. Unstable results in sensitivity analyses were marked as italic. Less than three studies were included in PU, Female of AU, ARU, Male of ARU subgroup of rs1801197, and AU, Male of AU subgroup of rs1042138, so that sensitivity analyses could not be performed. 
Significantly increased risk was also found in other four genetic models, however, the result in recessive model (TT vs. $\mathrm{CC}+\mathrm{CT}$ ) lacked stability, and we got a critical value of $\mathrm{u}$ in Begg's test in allelic comparison (T vs. C), heterozygote comparison (CT vs. CC) and dominant model (CT+TT vs. CC). Study NO 1.3 might play a negative role in the publication bias analyses.

In AU and its male subgroup of rs 1801197 , significantly increased risk was found in heterozygote comparison (CT vs. CC) and dominant model (CT+TT vs. CC). In AU, significantly increased risk was also found in allelic comparison (T vs. C) of rs1801197. However, those results lacked stability and publication bias analyses could not be performed.

In PU, Female of AU, ARU, Male of ARU subgroup of rs1801197, and AU, Male of AU subgroup of rs1042138, sensitivity analyses and publication bias analyses could not be performed.

Meanwhile, the limitations of this meta-analysis need to be addressed. To date, the number of available studies which could be included in this meta-analysis were small. Data for subgroup analyses were scanty. Sensitivity analyses and publication bias analyses could not be performed in some groups or subgroups. Studies NO 1.4, 1.5 and 1.5.1 had shown significant departure from HWE. Related studies published in other languages or unpublished were possibly missed. With those limitations, the study provided some insights on the potential association between CALCR gene polymorphims and calcium stone urolithiasis.

In conclusion, our results suggested that: CALCR rs1801197 might be associated with increased risk of calcium stone urolithiasis. There is insufficient data to fully confirm the association between CALCR rs1801197 and calcium stone urolithiasis susceptibility in pediatric urolithiasis, adult urolithiasis, adult recurrent urolithiasis subgroup and gender subgroup, and the results should be interpreted with caution. There is insufficient data to fully confirm the association between CALCR rs1042138 and calcium stone urolithiasis susceptibility, and the results should be interpreted with caution. Well-designed studies with larger sample size and more subgroups are required to validate the risk identified in the current meta-analysis.

\section{Funding}

This study was funded by:

1) The Science Fund founded by the First Affiliated Hospital of Xiamen University for Young Scholars (Project Number: XYY2016011; Recipient: Jiaxuan Qin).

2) Natural Science Foundation of Fujian (Project Number: 2017D0010; Recipient: Peide Bai).

3) Young and Middle-aged Backbone Talents Training Project of Fujian (Project Number: 2017-ZQN-81; Recipient: Peide Bai).

\section{CONFLICT OF INTEREST}

None declared.

\section{REFERENCES}

1. Danpure CJ. Genetic disorders and urolithiasis. Urol Clin North Am. 2000;27:287-99, viii.

2. Devuyst 0 , Pirson $Y$. Genetics of hypercalciuric stone forming diseases. Kidney Int. 2007;72:1065-72.

3. Lin HY, Harris TL, Flannery MS, Aruffo A, Kaji EH, Gorn A, et al. Expression cloning of an adenylate cyclase-coupled calcitonin receptor. Science. 1991;254:1022-4.

4. Copp DH, Cameron EC, Cheney BA, Davidson AG, Henze KG. Evidence for calcitonin--a new hormone from the parathyroid that lowers blood calcium. Endocrinology. 1962;70:638-49.

5. Zhang $\mathrm{H}$, Tao X, Wu J. Association of calcitonin receptor gene polymorphism with bone mineral density in postmenopausal Chinese women: a meta-analysis. Arch Gynecol Obstet. 2015;291:165-72.

6. Lee HJ, Kim SY, Kim GS, Hwang JY, Kim YJ, Jeong B, et al. Fracture, bone mineral density, and the effects of calcitonin receptor gene in postmenopausal Koreans. Osteoporos Int. 2010;21:1351-60.

7. Nakamura M, Zhang ZQ, Shan L, Hisa T, Sasaki M, Tsukino $\mathrm{R}$, et al. Allelic variants of human calcitonin receptor in the Japanese population. Hum Genet. 1997;99:38-41.

8. [Last accessed on June 21, 2017]. GA Wells, B Shea, D O'Connell, J Peterson, V Welch, M Losos, et al. The Newcastle-Ottawa Scale (NOS) for assessing the quality of nonrandomised studies in meta-analyses. Available from: <http://www.ohri.ca/programs/clinical_epidemiology/ nosgen.pdf> 
9. Moher D, Liberati A, Tetzlaff J, Altman DG; PRISMA Group. Preferred reporting items for systematic reviews and meta-analyses: the PRISMA statement. J Clin Epidemiol. 2009;62:1006-12.

10. Higgins JP, Thompson SG. Quantifying heterogeneity in a meta-analysis. Stat Med. 2002;21:1539-58.

11. DerSimonian R, Laird N. Meta-analysis in clinical trials. Control Clin Trials. 1986;7:177-88.

12. Begg CB, Mazumdar M. Operating characteristics of $a$ rank correlation test for publication bias. Biometrics. 1994;50:1088-101.

13. Egger M, Davey Smith G, Schneider M, Minder C. Bias in meta-analysis detected by a simple, graphical test. BMJ. 1997;315:629-34.

14. Aji K, Song GL, Yasen A, Azad B, Tursun H. [Association of vitamin $D$ receptor gene polymorphisms with urolithiasis in Uyghur children from southern Xinjiang, China]. Zhongguo Dang Dai Er Ke Za Zhi. 2012;14:956-9.

15. Franceschini N, Reiner A, Chi T, Stoller M, Kahn A, Carty C, Edwards T, Jackson R. Novel loci for kidney stone using diverse ancestry populations: The women's health initiative study. J Urol. 2012;187:e834-e5.

16. Yang Y, Wang SG, Ye ZQ, Yang WM. Single nucleotide polymorphism of calcitonin receptor gene and idiopathic hypercalciuria. Chinese Journal of Urology 2006;27: 695-8.

17. Bid HK, Chaudhary H, Mittal RD. Association of vitamin-D and calcitonin receptor gene polymorphism in paediatric nephrolithiasis. Pediatr Nephrol. 2005;20:773-6.
18. Song GL, Guo XL, Sun H, Anniwaer Yashen, Wang YJ. Correlation between calcitonin receptor gene polymorphism and upper urinary tract stone in Uyghur children in Xinjiang. Journal of Xinjiang Medical University 2014;37:1172-5.

19. Chen WC, Wu HC, Lu HF, Chen HY, Tsai FJ. Calcitonin receptor gene polymorphism: a possible genetic marker for patients with calcium oxalate stones. Eur Urol. 2001;39:716-9.

20. Shakhssalim N, Basiri A, Houshmand M, Pakmanesh H, Golestan B, Azadvari M, et al. Genetic polymorphisms in calcitonin receptor gene and risk for recurrent kidney calcium stone disease. Urol Int. 2014;92:356-62.

21. Mitra P, Guha M, Ghosh S, Mukherjee S, Bankura B, Pal $\mathrm{DK}$, et al. Association of calcitonin receptor gene (CALCR) polymorphism with kidney stone disease in the population of West Bengal, India. Gene. 2017;622:23-28.

\section{Correspondence address:} Jinchun Xing, MD, PhD Department of Urology Surgery, the First Affiliated Hospital of Xiamen University

Center of Diagnosis and Treatment of Urinary System Diseases, the First Affiliated Hospital of Xiamen University; the Key Laboratory of Urinary Tract Tumors and Calculi of Xiamen City, the First Affiliated Hospital of Xiamen University Xiamen, Fujian, China, 361003. E-mail: jinchun_xing@163.com 